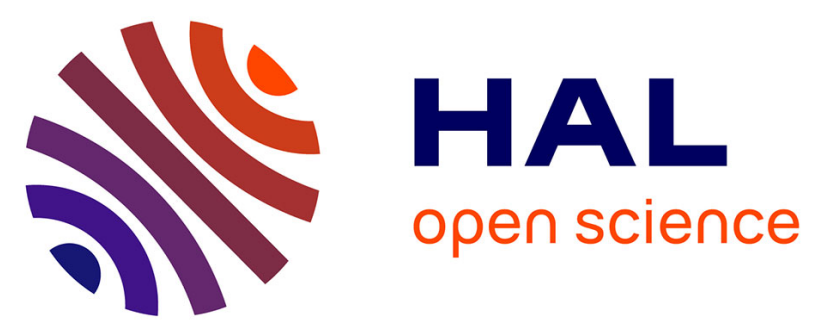

\title{
Flood simulation errors show an unexpected seasonal trend: results obtained on a set of 229 catchments and 11,054 flood events
}

Paul Astagneau, François Bourgin, Vazken Andréassian, Charles Perrin

\section{- To cite this version:}

Paul Astagneau, François Bourgin, Vazken Andréassian, Charles Perrin. Flood simulation errors show an unexpected seasonal trend: results obtained on a set of 229 catchments and 11,054 flood events. EGU General Assembly 2021, Apr 2021, Vienne, Austria. 10.5194/egusphere-egu21-1045 . hal-03265998

\section{HAL Id: hal-03265998 \\ https://hal.inrae.fr/hal-03265998}

Submitted on 21 Jun 2021

HAL is a multi-disciplinary open access archive for the deposit and dissemination of scientific research documents, whether they are published or not. The documents may come from teaching and research institutions in France or abroad, or from public or private research centers.
L'archive ouverte pluridisciplinaire HAL, est destinée au dépôt et à la diffusion de documents scientifiques de niveau recherche, publiés ou non, émanant des établissements d'enseignement et de recherche français ou étrangers, des laboratoires publics ou privés.

\section{(ㄷ)(1)}

Distributed under a Creative Commons Attribution| 4.0 International License 
EGU21-1045

https://doi.org/10.5194/egusphere-egu21-1045

EGU General Assembly 2021

(c) Author(s) 2021. This work is distributed under

the Creative Commons Attribution 4.0 License.

\section{Flood simulation errors show an unexpected seasonal trend: results obtained on a set of 229 catchments and 11,054 flood events}

Paul C. Astagneau, François Bourgin, Vazken Andréassian, and Charles Perrin

Université Paris-Saclay, INRAE, UR HYCAR, Antony, France (paul.astagneau@inrae.fr)

To improve the predictive capability of a model, one must identify situations where it fails to provide satisfactory results. We tried to identify the deficiencies of a lumped rainfall-runoff model used for flood simulation (the hourly GR5H-I model) by evaluating it over a large set of 229 French catchments and 11,054 flood events. Evaluating model simulations separately for individual flood events allowed us identifying a seasonal trend: while the model yielded good performance in terms of aggregated statistics, grouping results by season showed clear underestimations of most of the floods occurring in summer. The largest underestimations of flood volumes were identified when high-intensity precipitation events occurred and when the precipitation field was highly spatially variable. Low antecedent soil moisture conditions were also found to be strongly correlated with model bias. Overall, this study pinpoints the need to better account for shortduration processes to improve the GR5H-I model for flood simulation. 